Instructions for authors, subscriptions and further details:

http://ijep.hipatiapress.com

\title{
Digital Systems for Open Access to Formal and Informal Learning
}

Laura Martí Ros ${ }^{1}$

1) University of Lleida, Spain

Date of publication: October $24^{\text {th }}, 2015$

Edition period: October 2015 - February 2016

To cite this review: Martí Ros, L. (2015). [Review of the book Digital systems for open access to formal and informal learning by Sampson, D. G., Ifenthaler, D., Spector, J. M. \& Isaias, P.] International Journal of Educational Psychology, 4(3), 329-331. doi: 10.17583/ijep.2015.1720

To link this review: http://dx.doi.org/10.17583/ijep.2015.1720

\section{PLEASE SCROLL DOWN FOR ARTICLE}

The terms and conditions of use are related to the Open Journal System and to Creative Commons Attribution License (CC-BY). 
IJEP - International Journal of Educational Psychology, Vol. 4 No. 3 February 2015 pp. 329-331

\section{Review}

Sampson, D. G., Ifenthaler, D., Spector, J. M. \& Isaias, P. (Eds.) (2014). Digital systems for open access to formal and informal learning. Springer International Publishing.

Digital systems and services for technology-supported learning and education, referring to innovative methods, tools/systems and technologysupported services, are recognized as the key drivers to transform the way in which individuals, groups and organizations "learn" and "think". Wegerif (2015) argues that there is enough empirical evidence to support the claim that technology shapes thinking from within, developing thinking skills. On this view technology is not just seen as a means to deliver educational goals, but as something that ought to be taken into account in shaping those goals (Swan, Lin \& van't Hooft, 2008). These transformations influence: objectives - moving from acquiring new 'knowledge' to developing new and relevant 'competences', methods - moving from 'classroom'-based teaching to 'context-aware' personalized learning, and assessment - moving from 'lifelong' degrees and certifications to 'on-demand' and 'in-context' accreditation of qualifications. Within this context, promoting open access to formal and informal learning is currently a key issue in the public discourse and global dialogue on education.

These transformations boosted by technology have led to new research challenges which are discussed in this volume. This book captures the current state of the art in both Theory and Practice (Part I) and Methods and Technologies (Part II). The volume consists of 20 chapters selected from among peer-reviewed papers presented at the CELDA (Cognition and Exploratory Learning in the Digital Age) 2012 conference as well as scholars from around the world who were invited to contribute to this book with particular topics.

The book presents high standard research around the next five key themes in education:

a) The evolution of University Open Courses in transforming learning. The book brings new knowledge about how to face two educative challenges 
on this topic, on the one hand, how to design learner-centered online courses for the masses, facilitate students' engagement, commitment, and learner connectedness to the distributed resources. And, on the other hand, the book discusses the assessment of students learning online.

b) The construction of an educative framework to provide social features for building and sustaining web-based educational communities. In this view, two chapters in the book develop research insights in communities, one of them as a repository of best teaching practices from 2000 European schools and, another chapter, as an on-line educational portal to support open access to teaching and learning of people with disabilities.

c) Digital Game-Based Learning. The book explores three different areas in this field: i) learning theory that frame digital game design and its implementation in educational settings; ii) the role of digital games in enhancing entrepreneurship education; and iii) active creation of digital games as learning tools.

d) Mobile Learning. The book presents interesting research in science in which mobile data can play a significant role bringing ideas and data from the real world into the classroom. Students can work on these data, from a realistic point of view and can identify big scientific ideas.

e) Technology as an environment to support dialogic spaces to enhance group learning, group creativity and in promoting Learning to Learn together skills (L2L2) as key competences for the $21^{\text {st }}$ Century. The book presents research in designing high quality technology-enhanced learning environments to promote engagement and reflection about how we can better learn with other people.

An in-depth blueprint of the promise, potential, and imminent future of the field, Digital Systems for Open Access to Formal and Informal Learning is an essential reading for researchers and practitioners, as well as, undergraduate and postgraduate students, in educational technology and learning sciences. 


\section{References}

Swan, K., Lin, L., \& van't Hooft, M. (2008). Teaching with (digital) technology. In Lassonde, C.; Michael, R \& Rivera-Wilson (Eds.) Current issues in teacher education: History, perspectives and implications (pp. 171-188) Illinois: Charles Thomas Publisher.

Wegerif, R. (2015). Technology and teaching thinking. In Wegerif, R., Li, L. \& Kaufman, J. (Eds) The Routledge International Handbook of Research on Teaching Thinking, (pp. 427-440). New York: Routledge.

Laura Martí Ros Faculty of Education University of Lleida lauramarti@pip.udl.cat 